\title{
Cytokine expression in the uterus of mice with pregnancy loss: effect of maternal immunopotentiation with GM-CSF
}

\author{
S. Savion, E. Zeldich, H. Orenstein, J. Shepshelovich, \\ A. Torchinsky, H. Carp, V. Toder and A. Fein \\ Department of Embryology and Teratology, Sackler School of Medicine, Tel Aviv University, \\ Ramat Aviv, Tel Aviv 69978, Israel
}

It is believed that failure of the maternal immune system to actively support embryonic development, through production of the appropriate cytokine network, might be responsible for embryonic death. Thus, the aim of this study was to evaluate the possible involvement of cytokines such as tumour necrosis factor $\alpha$ (TNF- $\alpha)$ and transforming growth factor $\beta 2$ (TGF- $\beta 2$ ), which are crucial for normal embryonic development, in the early stages of mechanisms that mediate induced pregnancy loss. The early stages of the resorption process induced by lipopolysaccharide (LPS) were characterized by blood accumulation in the vicinity of the embryo, preceding any visible embryonic damage. At that time, immunohistochemical analysis revealed an increased expression of TNF- $\alpha$ in the primary and secondary decidua, which was reduced as the resorption process was completed. In contrast, TGF- $\beta 2$ expression was decreased in the primary and secondary decidua, as well as in the glandular epithelium, at all the times assessed. Maternal immunopotentiation with granulocyte macrophage-colony stimulating factor (GM-CSF), which controls maternal immune activities supporting normal embryonic development, decreased the resorption rate in LPS-treated mice while normalizing the expression of TNF- $\alpha$ and TGF- $\beta 2$ in the uterus of these animals throughout the ongoing resorption process. These results indicate a possible role for maternal immunopotentiation with GM-CSF in the mechanisms mediating the early stages of pregnancy loss, possibly via modulation of TNF- $\alpha$ and TGF- $\beta 2$ activity.

\section{Introduction}

Spontaneous abortions are among the most common complications of pregnancy and about $20 \%$ of pregnancies end in abortion during the first trimester (Clark and Chaouat, 1989). However, the mechanisms mediating the survival of the fetus or those leading to pregnancy loss are far from understood. It is believed that failure of the maternal immune system to actively support pregnancy, for example, by production of the appropriate cytokine network, may be one of the pathways responsible for embryonic death (Clark and Chaouat, 1989; Wegmann, 1990).

One such cytokine is tumour necrosis factor $\alpha$ (TNF- $\alpha$ ), a multifunctional cytokine that plays a prominent role in immune and host defence responses, as well as in the regulation of cellular proliferation, differentiation and death (Beutler and Cerami, 1989; Vassali, 1992). TNF- $\alpha$ may also be involved in the regulation of reproductive processes, including blastocyst growth and implantation, as well as normal placental growth and function (Hunt et al., 1990; Tartakovsky and Ben-Yair, 1991; Terranova et al., 1995). In addition, data obtained in several studies indicate that abnormal TNF- $\alpha$ production might be associated with

Email: shoshans@plato.tau.ac.il pregnancy failure. TNF- $\alpha$ concentration was increased significantly in the amniotic fluid of women suffering from uterine infections and its increased production correlates with the incidence of pre-term labour (Romero et al., 1989). In addition, administration of TNF- $\alpha$ to pregnant mice resulted in pregnancy loss or retardation of embryonic growth (Chaouat et al., 1991; Heyborne et al., 1992).

Another cytokine that may be involved in embryonic development is transforming growth factor $\beta 2$ (TGF- $\beta 2$ ), which has major effects on cell growth and differentiation, as well as on tissue remodelling and repair (Barnard et al., 1990; Roberts et al., 1990). TGF- $\beta 2$ is expressed in murine uterus throughout gestation (Cheng et al., 1993). In addition, a factor resembling TGF- $\beta 2$ in structure and bioactivity, which was detected in murine decidua and has immunosuppressive properties, may be involved in protection of the embryo from maternal immune effector cells (Clark et al., 1990). The requirement for TGF- $\beta 2$ for embryonic survival was validated further by experiments demonstrating an abortificient effect of anti TGF- $\beta 2$ antibodies, whereas women suffering from recurrent spontaneous abortions had a deficiency in decidual immunosuppressor cells producing TGF-32 (Clark et al., 1992; Lea et al., 1995).

The correlation between increased TNF- $\alpha$ expression or TGF- $\beta 2$ deficiency and pregnancy failure might indicate a possible association between normalization of the expression of both cytokines at the fetomaternal interface 
and an improved reproductive performance. Such an improvement is achieved by potentiation of the maternal immune system (immunopotentiation), either specifically with allogeneic leucocytes carrying the paternal major histocompatibility complex (MHC) haplotype (Coulam and Coulam, 1992) or nonspecifically with xenogeneic leucocytes (Torchinsky et al., 1995), complete Freund's adjuvant (Toder et al., 1990) or certain cytokines that are capable of controlling fetal survival (Tartakovsky and BenYair, 1991). Among others, granulocyte macrophagecolony stimulating factor (GM-CSF) was shown to support placental growth and function, as well as to decrease pregnancy loss (Wegmann et al., 1989; Chaouat et al., 1990). In addition, Savion et al. (1999) demonstrated the ability of maternal immunopotentiation with GM-CSF to affect embryonic growth and morphogenesis and, thus, to protect the embryo from the detrimental effects of embryotoxic agents. The exact mechanisms by which maternal immunopotentiation might affect embryonic survival and, thus, lead to an improved reproductive performance, are not yet fully understood. However, it can be assumed that an appropriate modulation of the cytokine network at the fetomaternal interface might support embryonic survival. Therefore, the aim of the present study was to evaluate possible changes in the expression of TNF- $\alpha$ or TGF- $\beta 2$ in the uterus of lipopolysaccharide (LPS)-treated mice in association with the early stages of the LPS-induced resorption process. In addition, the ability of maternal immunopotentiation with GM-CSF to affect the resorption rate, as well as the altered expression of TNF- $\alpha$ or TGF- $\beta 2$ in the uterus of LPS-treated mice, was assessed.

\section{Materials and Methods}

\section{Animals}

Eight- to twelve-week-old $\mathrm{C} 3 \mathrm{H}$ male and female mice were purchased from the Tel Aviv University animal facility and kept under standard conditions. Females were caged with males for $3 \mathrm{~h}$ (from 07:00 $\mathrm{h}$ to $10: 00 \mathrm{~h}$ ) and the presence of a vaginal plug was determined as day 1 of pregnancy.

\section{Induction and evaluation of pregnancy loss}

Pregnancy loss was induced in $\mathrm{C} 3 \mathrm{H}$ mice by LPS (Sigma, St Louis, MO), which was injected i.p. at $0.75 \mu \mathrm{g}$ $\left(0.2 \mathrm{ml} \mathrm{PBS}^{-1}\right.$ per mouse on day 9 of pregnancy. Uteri from mice in the non-treated $(n=10-12)$ and LPS-treated ( $n=16-18)$ groups were collected at 3, 6, 24 and $48 \mathrm{~h}$ after LPS treatment (days 9 and 10 of pregnancy), and the numbers of implantation sites, resorbing embryos and live embryos were recorded. Resorbing embryos were identified by their smaller size and dark red colour, resulting from the massive haemorrhage and clotting of blood that accompany the resorption process, compared with their healthy counterparts, which were pink and larger in size. The percentage of resorbing embryos was calculated by dividing the number of resorbing embryos by the number of implantation sites per mouse. The resorption process was investigated further in paraformaldehyde-fixed $(4 \%, \mathrm{w} / \mathrm{v})$ paraffin wax-embedded tissue sections (7 $\mu \mathrm{m}$ thickness), which were stained with haematoxylin and eosin and examined under a light microscope, as described by Savion et al. (2002).

\section{Immunopotentiation}

Immunopotentiation of the mice by murine recombinant GM-CSF (Peprotech, Rocky Hill, NJ) was performed twice, as described by Savion et al. (1999). In brief, under nembutal anaesthesia $\left(40 \mathrm{mg} \mathrm{kg}^{-1}\right)$, mice $(n=16-18)$ were injected with GM-CSF into the uterus on day 1 of pregnancy at $10 \mathrm{U}(0.04 \mathrm{ml} \mathrm{PBS})^{-1}$ per horn, followed by a second injection of $20 \mathrm{U}(0.03 \mathrm{ml} \mathrm{PBS})^{-1}$ per mouse into the tail vein on day 8 of pregnancy. Mice injected accordingly with PBS only were used as controls.

\section{Immunohistochemistry}

Tissue sections were deparaffinized and treated with $1.5 \mathrm{mg}$ hyaluronidase $\mathrm{ml}^{-1}$ (Sigma) in PBS, $\mathrm{pH}$ 6.5, for $1 \mathrm{~h}$ at $37^{\circ} \mathrm{C}$. Endogenous peroxidase activity was inhibited by incubating the sections for $15 \mathrm{~min}$ in $0.3 \%(\mathrm{v} / \mathrm{v})$ hydrogen peroxide and non-specific binding sites were blocked by incubation in $10 \%$ fetal calf serum (FCS) in PBS containing $0.5 \%(\mathrm{v} / \mathrm{v})$ Tween-20 (PBST) for $30 \mathrm{~min}$ at $37^{\circ} \mathrm{C}$. The sections were incubated overnight at $4^{\circ} \mathrm{C}$ with the primary antibodies diluted in 10\% FCS in PBST (rabbit anti-mouse TNF- $\alpha$ : $10 \mu \mathrm{g} \mathrm{ml}^{-1}$; Endogen, Woburn, MA; and rabbit antimouse TGF- $\beta 2$ : $2 \mu \mathrm{g} \mathrm{ml}-1$; Santa Cruz Biotechnologies, Santa Cruz, CA). Non-immune rabbit serum used at the same dilution as the primary antibodies was used as a negative control. The slides were washed in PBST and incubated for $30 \mathrm{~min}$ at room temperature with biotinylated goat anti-rabbit IgG (Jackson Immunoresearch laboratories, West Grove, PA) at $2 \mu \mathrm{g} \mathrm{ml}^{-1}$, followed by incubation for $20 \mathrm{~min}$ in streptavidin-conjugated horseradish peroxidase (streptavidin-HRP; Zymed Laboratories, San Francisco, CA) in PBST at $10 \mu \mathrm{g} \mathrm{ml}^{-1}$. TNF- $\alpha$ - or TGF- $\beta 2$-positive cells were visualized by incubating the sections for $5 \mathrm{~min}$ in the dark with $0.2 \mathrm{mg}$ diaminobenzidine $\mathrm{ml}^{-1}$ (Sigma) and $0.05 \%(\mathrm{v} / \mathrm{v})$ hydrogen peroxide, and the positive staining was amplified by a 10 min incubation at room temperature in $8 \%(\mathrm{w} / \mathrm{v}) \mathrm{CuSO}_{4}$. The sections were counterstained with $0.1 \%(\mathrm{v} / \mathrm{v})$ Meyer's haematoxylin, mounted in $59 \%(\mathrm{w} / \mathrm{v})$ glycerol- $-0.9 \%(\mathrm{w} / \mathrm{v})$ gelatin solution and examined under a light microscope.

\section{Densitometry}

Densitometric analysis of the immunohistochemical staining was performed by an Olympus Cue-2 Image Analysis System (Lake Success, NY) using software (Cue-2 Densitometry, version 4.0) developed by the Galai Corporation (Migdal Ha-Emek), as described by Fisher et al. 
(1998). For each experimental group, three or four implantation sites from different litters were collected and two or three sections from each implantation site were analysed, giving a total of $6-12$ sections per group. Three or four fields within each area were measured for each section and the results of all sections from each experimental group were averaged. Final values of absorbance measured for the various areas of the uterus were calculated by subtraction of values determined in sections from the same experimental group, which were treated with non-immune rabbit serum instead of the primary antibodies, or processed in their absence.

\section{Statistical analysis}

Statistical analysis of reproductive performance was performed on a litter basis. The GT2 method for multiple comparisons (Sokol and Rohlf, 1995) was used for statistical analysis of all data obtained. The two-tailed level of significance of differences was $P<0.05$.

\section{Results}

\section{Characterization of the resorption process}

A mouse model in which pregnancy loss was induced by injecting $\mathrm{C} 3 \mathrm{H}$ mice with LPS at $0.75 \mu$ g per mouse was used throughout the study. At $3 \mathrm{~h}$ after LPS treatment, most of the embryos appeared morphologically intact and only $14 \%$ resorbing embryos could be detected in the LPS-treated mice compared with about $11 \%$ in the non-treated mice (Fig. 1). At $6 \mathrm{~h}$ after LPS injection, 43\% resorbing embryos were detected in the LPS-treated mice compared with about $8 \%$ in the non-treated mice (Fig. 1) The percentage of resorbing embryos had increased significantly by $24 \mathrm{~h}$ after LPS treatment, reaching about $70 \%$, compared with $12 \%$ in the non-treated mice (Fig. 1), whereas by $48 \mathrm{~h}$ after treatment, the resorption process was complete and all the embryos were fully resorbed (data not shown). In accordance with our previous study (Savion et al., 2002), the resorption process was accompanied by accumulation of blood in the vicinity of the embryo, which became visible as early as $3 \mathrm{~h}$ after LPS treatment in $>90 \%$ of the embryos and preceded any morphological embryonic damage. As the resorption process continued, $100 \%$ of the embryos showed massive morphological damage, further blood accumulation and large infiltrates of leucocytes, and were resorbed fully by $48 \mathrm{~h}$ after LPS treatment (Savion et al., 2002).

\section{Effect of maternal immunopotentiation on the LPS- induced resorption process}

The effect of maternal immunopotentiation with GM-CSF on the LPS-induced resorption process was tested at various times after LPS treatment. At $3 \mathrm{~h}$ after LPS treatment, the percentage of resorbing embryos collected from

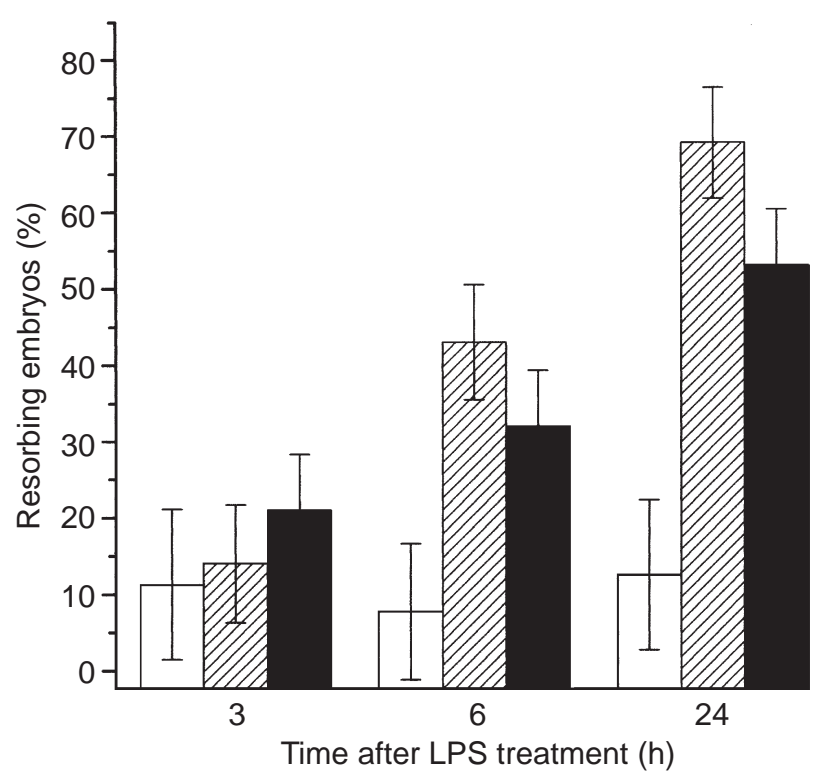

Fig. 1. Percentage of resorbing embryos (mean $\pm \mathrm{SE}$ ) in nontreated ( $\square ; n=10-12)$, lipopolysaccharide (LPS)-treated (罝; $n=16-18)$ or immunopotentiated and LPS-treated ( $\mathbf{\square} ; n=16-18$ ) mice, at various times after LPS treatment. Data are presented as $95 \%$ limits for the mean calculated by the GT2 method. Means with limits that do not overlap are significantly different.

immunopotentiated and LPS-treated females did not differ significantly from that found in mice treated with LPS only (Fig. 1). At $6 \mathrm{~h}$ as well as at $24 \mathrm{~h}$ after treatment, a decreased percentage of resorbing embryos was detected after GMCSF immunopotentiation, which was significant $(P<0.05)$ at $24 \mathrm{~h}$ after LPS treatment. In parallel, maternal immunopotentiation also decreased the percentage of embryos that demonstrated blood accumulation in their vicinity; however, the differences were not statistically significant (data not shown).

\section{TNF- $\alpha$ expression in the uterus of LPS-treated mice}

Expression of TNF- $\alpha$ in the uterus of LPS-treated mice was analysed at various time points after treatment to establish a possible role for TNF- $\alpha$ in pregnancy loss. Immunohistochemical analysis revealed that TNF- $\alpha$ was expressed in the primary decidua (the immediate surrounding of the embryo), as well as in the secondary decidua (distant to the embryos) (Figs 2a and 3a, respectively). LPS treatment resulted in increased expression of TNF- $\alpha$ in the primary and secondary decidua at $3 \mathrm{~h}$ (Figs 2b, $3 \mathrm{~b}$ and 4 ) and $6 \mathrm{~h}$ (data not shown and Fig. 4) after treatment, which was found by densitometric analysis to be significant $(P<0.05)$ for both the primary and secondary decidua (data not shown and Fig. 4, respectively). However, at $24 \mathrm{~h}$ after LPS treatment, when the resorption process was almost complete, the expression of TNF- $\alpha$ that was increased in the early stages of the resorption process 

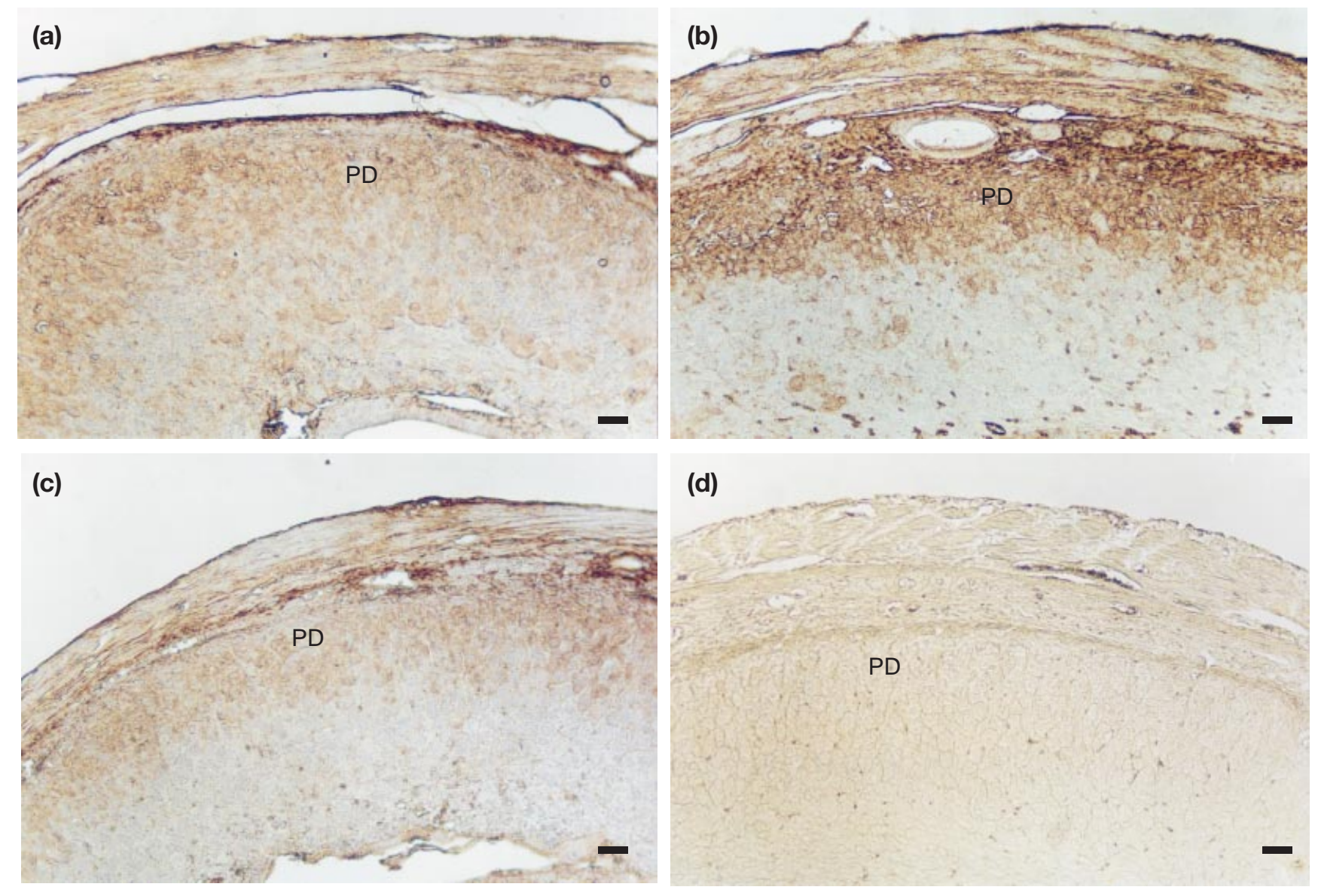

Fig. 2. Immunohistochemical analysis of tumour necrosis factor $\alpha$ (TNF- $\alpha$ )-positive cells in the primary decidua (PD) collected from (a) non-treated, (b) lipopolysaccharide (LPS)-treated or (c) immunopotentiated and LPS-treated mice, at $3 \mathrm{~h}$ after treatment. (d) Negative control: primary decidua from non-treated mice stained with non-immune rabbit serum. Scale bars represent $50 \mu \mathrm{m}$.

was decreased in the primary (data not shown), as well as in the secondary (Fig. 4), decidua. No differences in expression of TNF- $\alpha$ were observed in the uteri of nontreated animals at the times tested (Fig. 4).

\section{TGF- $\beta 2$ expression in the uterus of LPS-treated mice}

Expression of TGF- $\beta 2$ in the uterus of LPS-treated mice was examined to investigate the possibility that changes in its expression might correlate with the ongoing resorption process. TGF- $\beta 2$ was expressed in the uteri of nontreated mice, especially in the primary (Fig. 5a) and secondary (data not shown) decidua, as well as in the glandular epithelium (Figs 6a and 7). Expression of the cytokine did not change significantly at the times tested (Fig. 7). LPS treatment initiated the resorption process and also resulted in a clear decrease in TGF- $\beta 2$ expression in the primary (Fig. 5b) and secondary (data not shown) decidua, as well as in the glandular epithelium (Fig. 6b). The decrease in TGF- $\beta 2$ expression was detected at all the times tested (Fig. 7) and was significant $(P<0.05)$ for the glandular epithelium (Fig. 7) and the primary decidua (data not shown).

\section{Changes in uterine TNF- $\alpha$ and TGF- $\beta 2$ expression after maternal immunopotentiation with GM-CSF}

As maternal immunopotentiation with GM-CSF reduced the rate of resorption, it was investigated further whether this effect might be associated with normalization of the expression of TNF- $\alpha$ and TGF- $\beta 2$ that was altered by LPS treatment. Indeed, the increased TNF- $\alpha$ expression demonstrated in the primary and secondary decidua at 3 and $6 \mathrm{~h}$ after LPS treatment was decreased after maternal immunopotentiation (Figs 2c, 3c and data not shown, respectively), and was significant $(P<0.05)$ for the secondary decidua at $6 \mathrm{~h}$ after LPS treatment (Fig. 4). Furthermore, the TNF- $\alpha$ expression that was decreased $24 \mathrm{~h}$ after LPS treatment, was increased by maternal immunopotentiation in both the primary and secondary decidua, reaching nearly the level demonstrated in the uteri of nontreated animals (data not shown and Fig. 4, respectively). In 

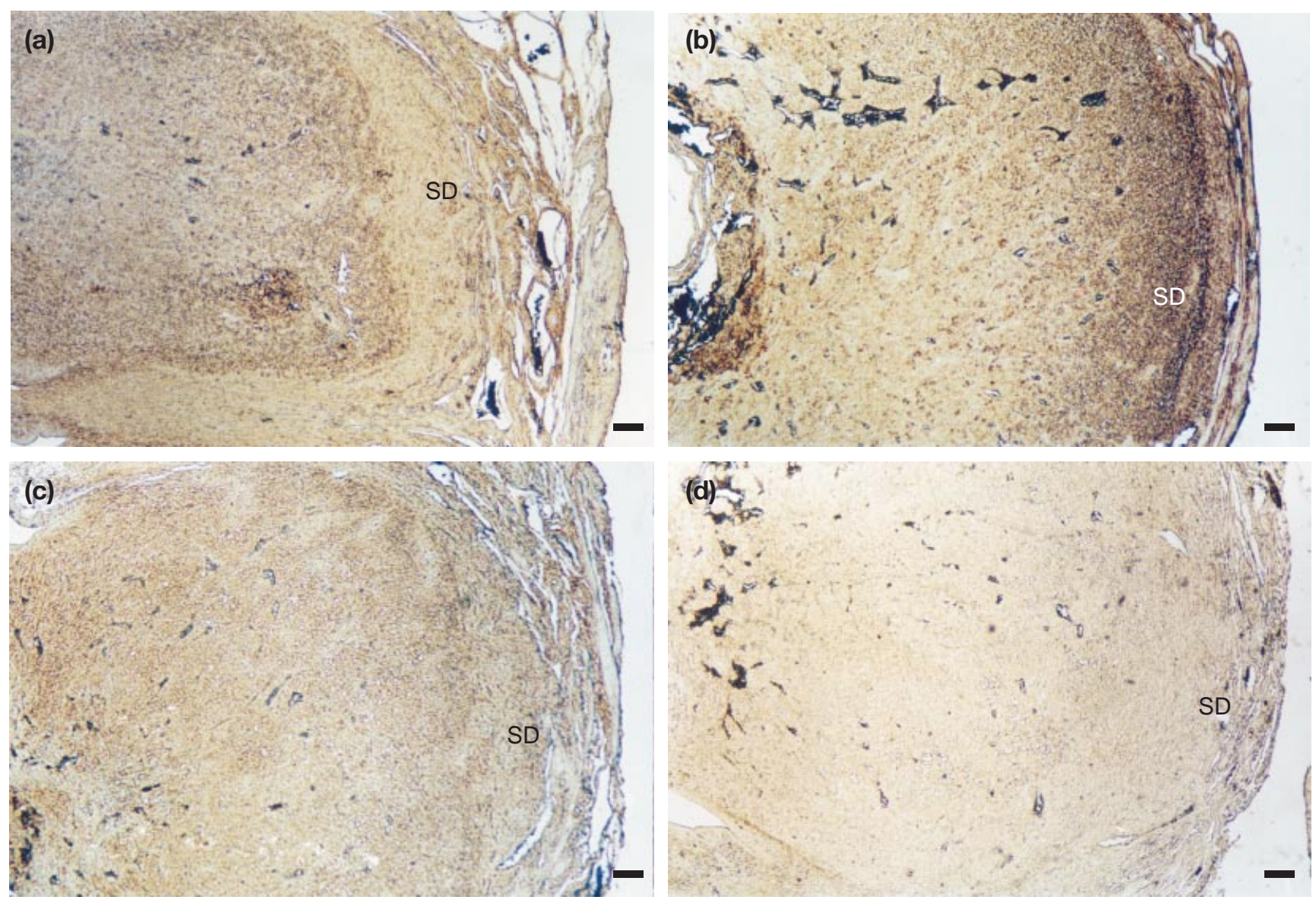

Fig. 3. Immunohistochemical analysis of tumour necrosis factor $\alpha$ (TNF- $\alpha$ )-positive cells in the secondary decidua (SD) collected from (a) non-treated, (b) lipopolysaccharide (LPS)-treated or (c) immunopotentiated and LPS-treated mice, at $3 \mathrm{~h}$ after treatment. (d) Negative control: secondary decidua from non-treated mice stained with non-immune rabbit serum. Scale bars represent $100 \mu \mathrm{m}$.

contrast, the TGF- $\beta 2$ expression that was reduced by LPS treatment at all the times tested was increased significantly $(P<0.05)$ by maternal immunopotentiation, almost to the level in the uteri of non-treated mice (Fig. 7). This normalizing effect of maternal immunopotentiation by GMCSF was evident in the primary decidua (Fig. 5c) and in the glandular epithelium (Figs $6 \mathrm{c}$ and 7 ), as well as in the secondary decidua (data not shown).

\section{Discussion}

Cytokines are important regulators of different cellular processes including cell growth, differentiation and death (Robertson et al., 1994; Lea et al., 1999). TNF- $\alpha$ and TGF$\beta 2$ are involved in the regulation of placental growth and function, as well as in embryonic development and survival (Lea et al., 1992; Wride and Semders, 1995; Hunt et al., 1996; Godkin and Dore, 1998). As the role of these cytokines in the mechanisms mediating pregnancy loss is not well understood, the aim of the present study was to characterize the patterns of TNF- $\alpha$ and TGF- $\beta 2$ expression in the uterus of $\mathrm{C} 3 \mathrm{H}$ mice and to correlate them with the ongoing resorption process induced in these mice by LPS. This model has already been used in various studies for the investigation of induced pregnancy loss; however, the abortificient effect of LPS has always been demonstrated at the endpoint of the resorption process, when most of the embryos are fully resorbed (Chaouat et al., 1990; Gendron et al., 1990; Chaouat, 1994; Baines et al., 1996). Therefore, we tried to follow up possible changes in TNF- $\alpha$ and TGF- $\beta 2$ expression associated with the initial stages of the LPS-induced resorption process. In accordance with our previous study (Savion et al., 2002), the early stages of the resorption process were characterized by blood accumulation in the vicinity of the embryo and infiltration of leucocytes, while most of the embryos showed no visible damage. At that time, an increase in the expression of TNF$\alpha$ was detected in the uterus of these animals, whereas at $24 \mathrm{~h}$ after treatment, when the resorption process was almost complete and most of the embryos were almost fully resorbed, the expression of TNF- $\alpha$ was decreased. An increase in TNF- $\alpha$ expression has also been demonstrated 


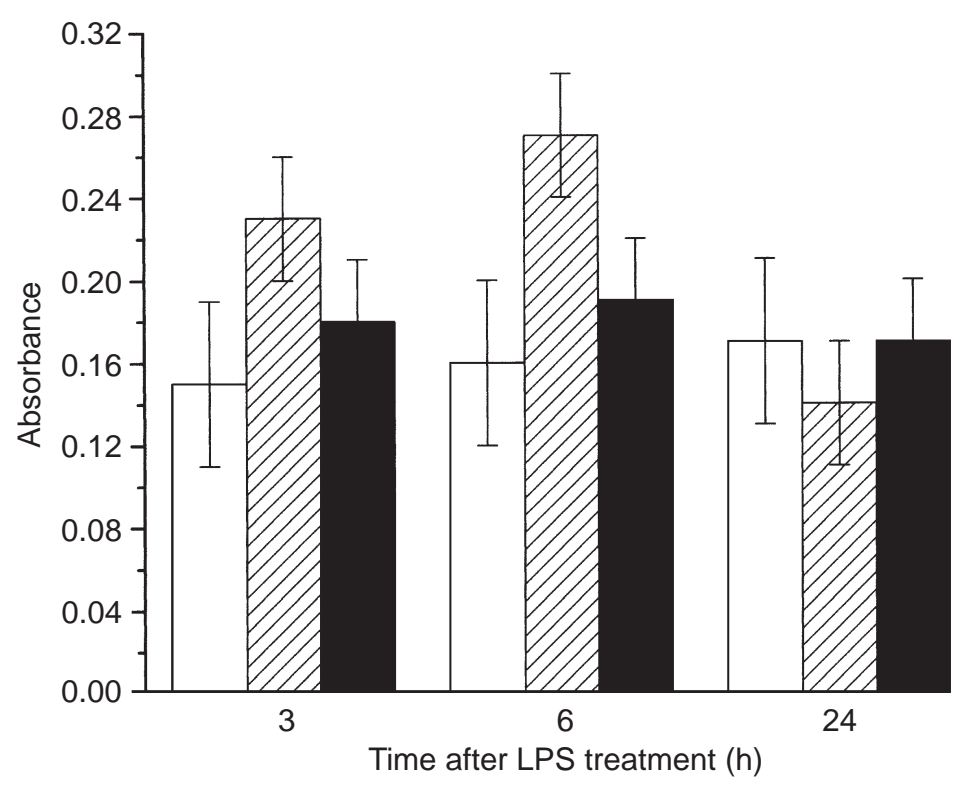

Fig. 4. Densitometric analysis of tumour necrosis factor $\alpha$ (TNF- $\alpha)$ expression (mean absorbance $\pm \mathrm{SD}$ ) in the secondary decidua collected from non-treated $(\square)$, lipopolysaccharide (LPS)-treated (四) or immunopotentiated and LPS-treated ( $\mathbf{\square})$ mice, at various times after treatment. For each experimental group, three or four implantation sites from different litters were collected and two or three sections from each implantation site were analysed (three or four fields within each measured area) and averaged. Data are presented as 95\% limits for the mean calculated by the GT2 method. Means with limits that do not overlap are significantly different.

in other models of pregnancy loss, mainly in the $\mathrm{CBA} / \mathrm{JDBA} / 2 \mathrm{~J}$ combination without further treatment (Tangri and Raghupathy, 1993) or after exposure to stress (Arck et al., 1995). Reznikov et al. (1999) demonstrated increased TNF- $\alpha$ expression in the uterus of mice that received an intrauterine inoculation of a high dose of LPS on days 14-15 of pregnancy. However, in these studies, TNF- $\alpha$ expression was assessed at the end of the resorption process, whereas in the present study, increased TNF- $\alpha$ expression is demonstrated in association with the initial stages of the resorption process, preceding any visible damage to the embryo itself. Our results support those of Gendron et al. (1990), who demonstrated increased TNF- $\alpha$ expression in the amniotic fluid of mice injected with a high dose of LPS on day 12 of pregnancy, at $2 \mathrm{~h}$ after treatment. The results of the present study are also in agreement with two other studies performed in our laboratory in which increased expression of TNF- $\alpha$ mRNA and protein preceded the final stages of the resorption process, induced by either cyclophosphamide treatment (Gorivodsky et al., 1998) or maternal diabetes (Fein et al., 2001). It should be noted that the increase in TNF- $\alpha$ expression in the uterus of LPStreated mice precedes the apoptotic process that occurs in association with the ongoing resorption (Savion et al., 2002). Moreover, the decreased TNF- $\alpha$ expression noted at the peak of the resorption process, which coincided with the peak of the apoptotic process (Savion et al., 2002), concurs with the known role of this cytokine in the induction and regulation of apoptosis (Wride and Semders, 1995; Hunt et al., 1996). These data are supported by another study performed in our laboratory, in which increased TNF- $\alpha$ expression was demonstrated in embryonic organs after exposure to cyclophosphamide, which preceded the apoptotic process and the appearance of malformations induced by cyclophosphamide treatment in these organs (Ivnitsky et al., 1998). Together, these results implicate TNF$\alpha$ in initiation of the LPS-induced resorption process.

In parallel, possible changes in TGF- $\beta 2$ expression in the uterus of LPS-treated mice that might be associated with the early stages of the resorption process were evaluated. Indeed, a decreased expression of TGF- $\beta 2$ in the decidua at the early as well as the late stages of the LPS-induced resorption process was observed. Our results are supported by other studies showing that decidual TGF- $\beta 2$ is either absent or is present at a low level in mice undergoing fetal resorptions and in women suffering from recurrent abortions (Lea et al., 1995; Clark et al., 1997; Raghupathy, 1997). Most of the work in mice is performed in the $\mathrm{CBA} / \mathrm{J} \times \mathrm{DBA} / 2 \mathrm{~J}$ model without further treatment or after exposure to stress, as well as in CB-17 SCID mice. In these studies, the high resorption rate was accompanied by increased TNF- $\alpha$ as well as decreased TGF- $\beta 2$ expression 

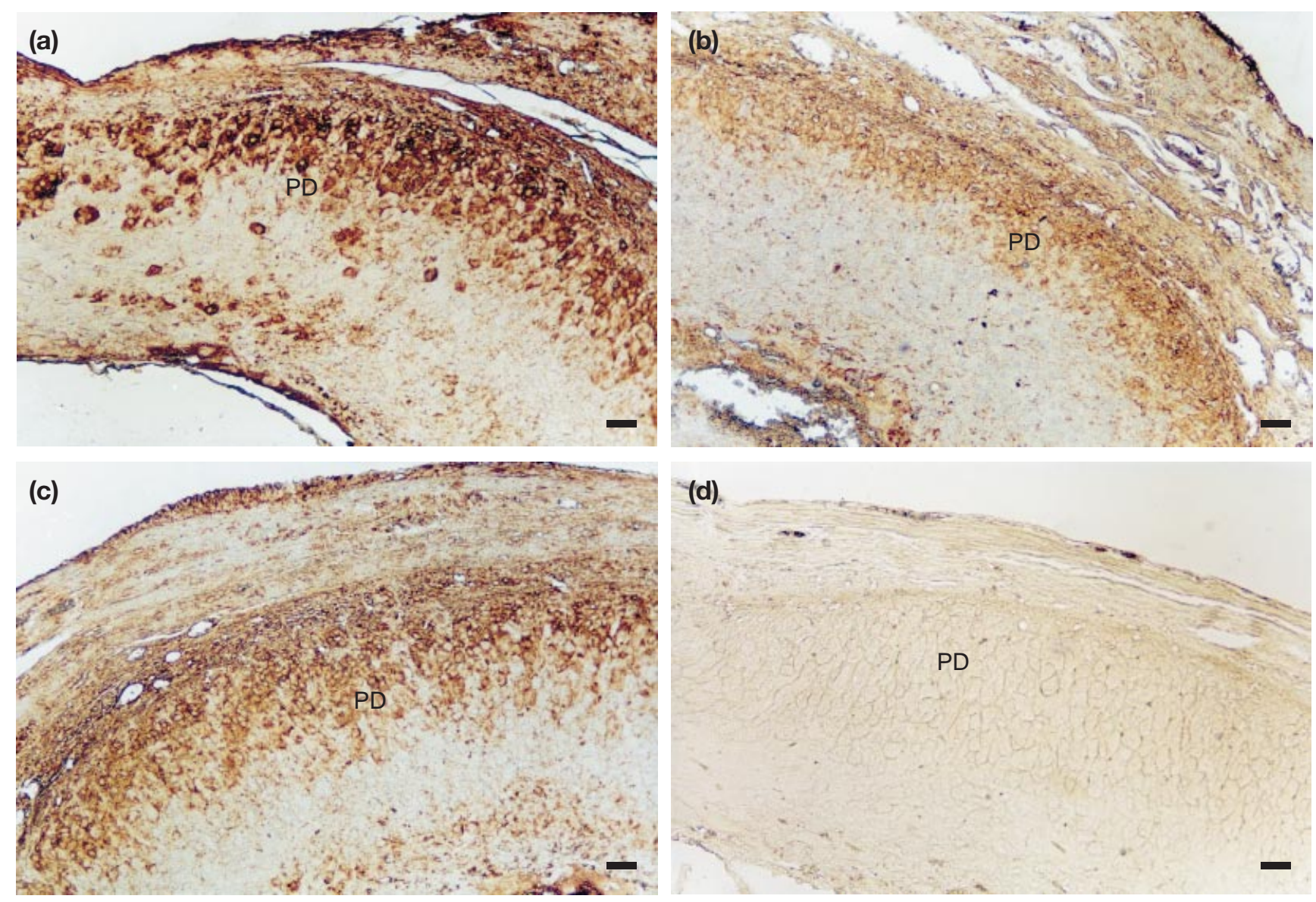

Fig. 5. Immunohistochemical analysis of transforming growth factor $\beta 2$ (TGF- $\beta 2$ )-positive cells in the primary decidua (PD) collected from (a) non-treated, (b) lipopolysaccharide (LPS)-treated or (c) immunopotentiated and LPS-treated mice, at $6 \mathrm{~h}$ after treatment. (d) Negative control: primary decidua from non-treated mice stained with non-immune rabbit serum. Scale bars represent $50 \mu \mathrm{m}$.

in the decidua of these animals (Clark et al., 1994; Arck et al., 1995). However, in these studies TGF- $\beta 2$ expression was assessed at the late stages of the resorption process, unlike in the present study, in which the decrease in TGF- $\beta 2$ expression preceded the peak of the process, when the embryos show normal morphology except for some blood accumulation in their vicinity. Our data also concur with the known role of TGF- $\beta 2$ as an immunosuppressive factor protecting the embryo from attack by maternal natural killer and cytotoxic $\mathrm{T}$ cells, which are involved in resorption processes leading to embryo death (Clark et al., 1992, 1997; Godkin and Dore, 1998). In addition, there is evidence that TGF- $\beta 2$ can deviate maternal immune responses toward the production of Th2 cytokines that support pregnancy, possibly via regulation or suppression of the Th1 cytokines that are detrimental for pregnancy (Maeda and Shiraishi, 1996; Arck et al., 1997; Raghupathy, 1997; Clark et al., 1999). Therefore, the decrease in decidual TGF- $\beta 2$ expression in the initial stages of the resorption process might be implicated as one of the events responsible for the LPS-induced embryonic death.
There is evidence to indicate that the involvement of the maternal immune system in the normal course of pregnancy might be extended further toward the protection of the embryo from embryotoxic factors (Gorivodsky et al., 1998; Clark et al., 1999; Gorivodsky et al., 1999). In the present study, we attempted to achieve this protective effect by potentiation of the maternal immune system with GM-CSF, which has protective and therapeutic properties (Talmadge et al., 1989; Neta, 1990; Neta et al., 1998) and exerts a direct effect on trophoblast or decidual cells, as well as acting as a powerful mediator of the immune activities that support normal embryonic development (Wegmann et al., 1989; Chaouat et al., 1990). Indeed, maternal immunopotentiation with GM-CSF decreased the resorption rate at 6 and $24 \mathrm{~h}$ after LPS treatment, as well as the percentage of embryos showing blood accumulation in their vicinity, as compared with the non-immunopotentiated and LPStreated group. These results are in agreement with other studies demonstrating the ability of GM-CSF to protect the embryo from the embryotoxic effects of cyclophosphamide or to reduce the resorption rate in the $\mathrm{CBA} / \mathrm{J} \mathrm{DBA} / 2 \mathrm{~J}$ 

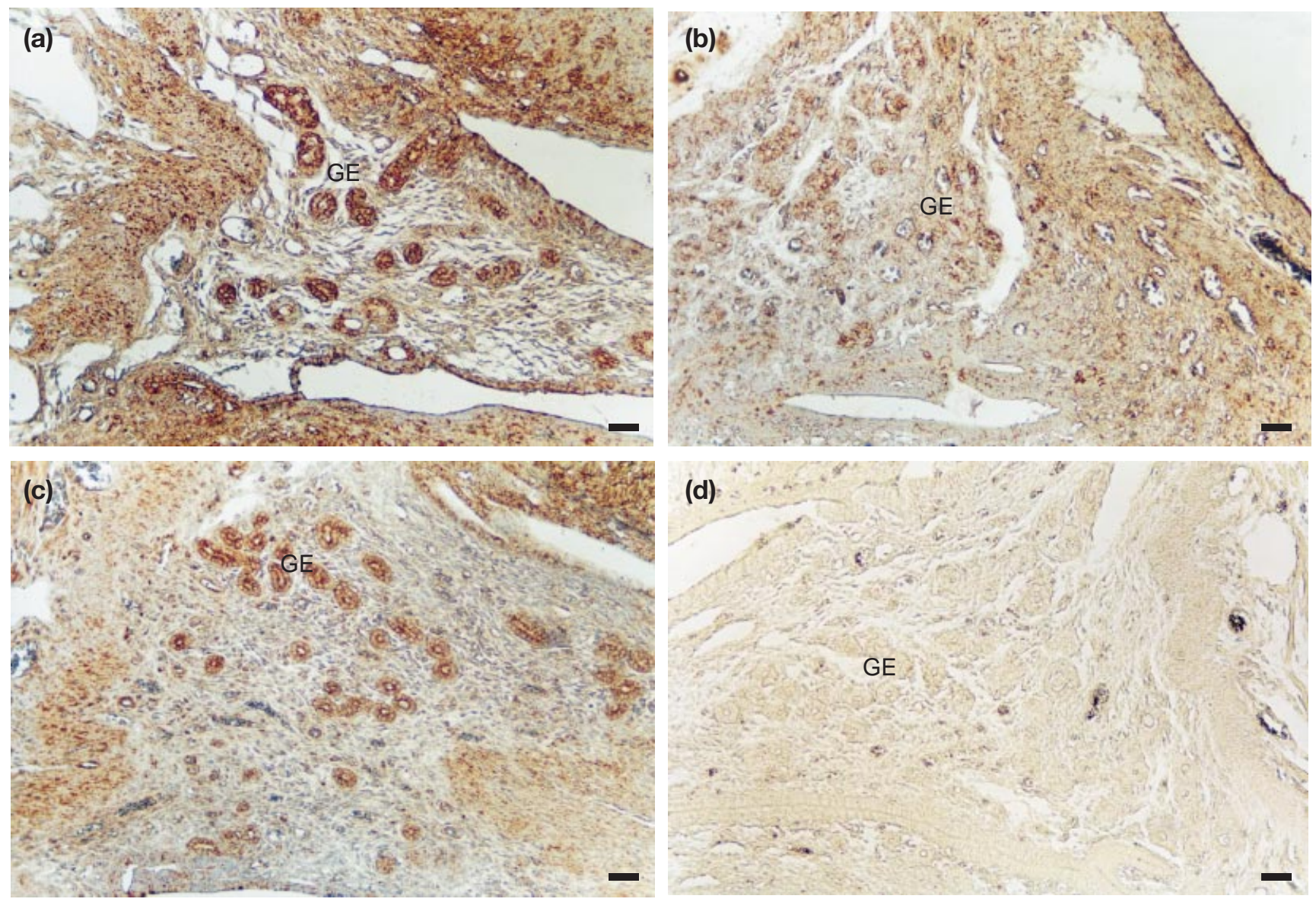

Fig. 6. Immunohistochemical analysis of transforming growth factor $\beta 2$ (TGF- $\beta 2$ )-positive cells in the glandular epithelium (GE) collected from (a) non-treated, (b) lipopolysaccharide (LPS)-treated or (c) immunopotentiated and LPS-treated mice, at $6 \mathrm{~h}$ after treatment. (d) Negative control: glandular epithelium from non-treated mice stained with non-immune rabbit serum. Scale bars represent $50 \mu \mathrm{m}$.

combination (Chaouat et al., 1990; Chaouat, 1994; Clark et al., 1994; Savion et al., 1999). To understand the mechanisms by which GM-CSF immunopotentiation might affect the resorption rate, we tested the possibility that alteration of TNF- $\alpha$ and TGF- $\beta 2$ expression in the uterus of LPS-treated mice might be associated with such an effect. Indeed, it was demonstrated that maternal immunopotentiation with GM-CSF partially normalized the expression of both cytokines in the uterus of LPS-treated mice. Thus, in immunopotentiated and LPS-treated mice, TNF- $\alpha$ expression was reduced in the initial stages of the resorption and increased later, as the process was completed. In addition, TGF- $\beta 2$ expression was significantly increased in GM-CSFimmunopotentiated and LPS-treated mice at all the times tested, as compared with mice treated with LPS only. These results are in agreement with those of Arck et al. (1995) in the $\mathrm{CBA} / \mathrm{J} \times \mathrm{DBA} / 2 \mathrm{~J}$ combination, demonstrating a decrease in TNF- $\alpha$ as well as an increase in TGF- $\beta 2$ expression in decidual supernatants collected from Balb/cimmunopotentiated $\mathrm{CBA} / \mathrm{J}$ mice after exposure to stress. However, both cytokines were assessed at the end of the resorption process, while in the present study the normalization of TNF- $\alpha$ and TGF- $\beta 2$ expression by GM-CSF preceded any visible damage to the embryo, occurring at the initial stages of the resorption process. Several studies performed in our laboratory also demonstrate that the ability of maternal immunopotentiation to reduce the resorption rate in cyclophosphamide-treated or diabetic mice is accompanied by normalization of TNF- $\alpha$ and TGF- $\beta 2$ expression in the uterus of these animals (Gorivodsky et al., 1998, 1999; Fein et al., 2001, 2002). The mechanisms by which GM-CSF alters TNF- $\alpha$ and TGF- $\beta 2$ expression may depend on the cells expressing these cytokines in the decidua. This heterogeneous population includes, in addition to decidual cells, macrophages and neutrophils, as well as natural killer and T cells. Thus, GM-CSF was shown to regulate the proliferation and function of macrophages and neutrophils, either by downregulation of TNF- $\alpha$ production by these cells (Clark and Chaouat, 1989; Robertson et al., 1994) or by maintenance of the immunosuppressive phenotype of macrophages through upregulation of their TGF-32 production (Robertson et al., 1994). GM-CSF was 


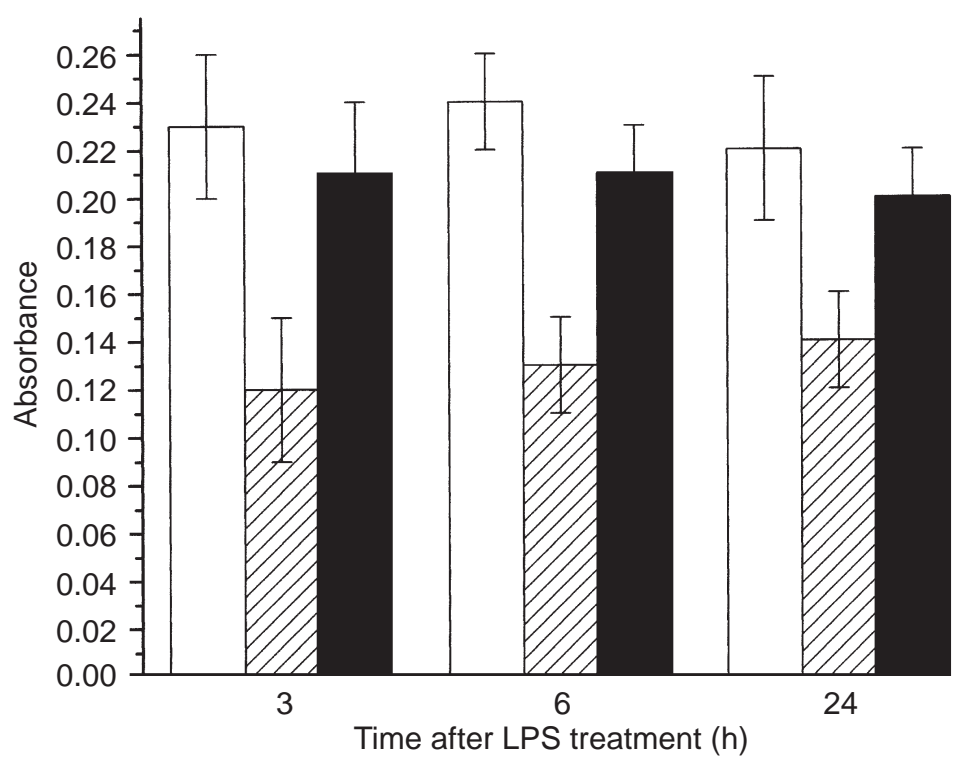

Fig. 7. Densitometric analysis of transforming growth factor $\beta 2$ (TGF- $\beta 2$ ) expression (mean absorbance $\pm \mathrm{SD}$ ) in the glandular epithelium collected from non-treated ( $\square$ ), lipopolysaccharide (LPS)-treated (四) or immunopotentiated and LPS-treated ( $\square$ ) mice at various times after treatment. For each experimental group, three or four implantation sites from different litters were collected and two or three sections from each implantation site were analysed (three or four fields within each measured area) and averaged. Data are presented as 95\% limits for the mean calculated by the GT2 method. Means with limits that do not overlap are significantly different.

also shown to prevent resorptions and to enhance trophoblast growth indirectly by downregulation of the cytotoxic activity of natural killer cells that might be mediated by their production of TNF- $\alpha$. This protective function of GM-CSF may be realized through activation of CD8-positive suppressor T cells, possibly via their production of TGF- $\beta 2$ (Clark et al., 1999). Another possibility that cannot be excluded is a direct effect of GM-CSF on ectoplacental cone trophoblast cells, residing in close proximity to the embryo on days 9-10 of pregnancy, that, in turn, might affect the expression of either TNF- $\alpha$ or TGF- $\beta 2$ by neighbouring decidual cells (Chaouat et al., 1990). Together, these data indicate that potentiation of the uterine local immune microenvironment by GM-CSF towards production of pregnancy-promoting cytokines such as TGF- $\beta 2$ and downregulation of TNF- $\alpha$, which is involved in pregnancy loss, might serve as key events in the mechanisms mediating the beneficial effects of maternal immunopotentiation on fetal survival and pregnancy outcome.

In conclusion, the results presented in the present study indicate a possible correlation between the altered decidual expression of TNF- $\alpha$ and TGF- $\beta 2$, and the LPS-induced resorption process. More than that, our data implicate maternal immunopotentiation by GM-CSF as a mechanism for protecting the embryo from LPS-induced pregnancy loss, possibly via modulation of TNF- $\alpha$ and TGF- $\beta 2$ activity.
This work was partially supported by grants from the Israel Science Foundation founded by the Israel Academy of Sciences and Humanities and the Israel Ministry of Health. The secretarial help of O. Lachover is highly appreciated.

\section{References}

Arck PC, Merali FS, Manuel J, Chaouat G and Clark DA (1995) Stresstriggered abortion: inhibition of protective suppression and promotion of tumor necrosis factor- $\alpha(\mathrm{TNF}-\alpha)$ release as a mechanism triggering resorptions in mice American Journal of Reproductive Immunology 33 74-80

Arck PC, David A, Ferrick DA, Steele-Norwood D, Croitoru K and Clark DA (1997) Regulation of abortion by $\gamma \delta \mathrm{T}$ cells American Journal of Reproductive Immunology 37 87-93

Baines MG, Duclos AJ, de Fougerolles AR and Gendron RL (1996) Immunological prevention of spontaneous early embryo resorption is mediated by non-specific immunostimulation American Journal of Reproductive Immunology 35 34-42

Barnard JA, Lyons RM and Moses HL (1990) The cell biology of transforming growth factor- $\beta$ Biochemica et Biophysica Acta 1032 79-87

Beutler B and Cerami A (1989) The biology of cachectin/TNF- $\alpha$ primary mediator of the host response Annual Reviews of Immunology 7 625-655

Chaouat G (1994) Synergy of lipopolysaccharide and inflammatory cytokines in murine pregnancy: alloimmunization prevents abortion but does not affect the induction of preterm delivery Cellular Immunology $157328-333$ 
Chaouat G, Menu E, Clark DA, Dy M, Minkowsky M and Wegmann TG (1990) Control of fetal survival in CBA $\times$ DBA $/ 2$ mice by lymphokine therapy Journal of Reproduction and Fertility 89 447-458

Chaouat G, Menu E, Szeerkeres-Bartho J, Rebut-Bonneton C, Bustany P, Kinsky R and Clark DA (1991) Immunological and endocrinological factors that contribute to a successful pregnancy. In Molecular and Cellular Immunology of the Fetal-Maternal Interface pp 277-287 Eds TG Wegmann, TG Gill and R Nisbet-Brown. Oxford University Press, New York

Cheng H-L, Schneider SL, Kane CM, Gollnick SO, Grande C, Thompson D, Pietrzak E and Tomasi TB (1993) TGF- $\beta 2$ gene and protein expression in maternal and fetal tissues at various stages of murine development Journal of Reproductive Immunology 25 133-148

Clark DA and Chaouat G (1989) What do we know about spontaneous abortion mechanisms? American Journal of Reproductive Immunology $1928-37$

Clark DA, Flanders KC, Banwatt D, Millar-Brook W, Manuel J, StedronskaClark J and Rowley B (1990) Murine pregnancy decidua produces a unique immunosuppressive molecule related to transforming growth factor $\beta 2$ Journal of Immunology 144 3008-3014

Clark DA, Lea RG, Flanders KC, Banwatt D and Chaouat G (1992) Role of a unique species of TGF- $\beta$ in preventing rejection of the conceptus during pregnancy. In Progress in Immunology VIII pp 841-849 Eds J Gergely, M Benczur and $\mathrm{N}$ abd Erdei. Springer-Verlag, Budapest

Clark DA, Quarrington C, Banwatt D, Manuel J and Fulop G (1994) Spontaneous abortion in immunodeficient SCID Mice American Journal of Reproductive Immunology 32 15-25

Clark DA, Merali FS, Hoskin DW, Steele-Norwood D, Arck PC, Croitoru K, Murgita RA and Hirte H (1997) Decidue-associated suppressor cells in abortion-prone $\mathrm{DBA} / 2$-mated $\mathrm{CBA} / \mathrm{J}$ mice that release bioactive transforming growth factor $\beta 2$-related immunosuppressive molecules express a bone marrow-derived natural suppressor cell marker and $\gamma \delta$ T-cell receptor Biology of Reproduction 56 1351-1360

Clark DA, Arck PC and Chaouat G (1999) Why did your mother reject you? Immunogenetic determinants of the response to environmental selective pressure expressed at the uterine level American Journal of Reproductive Immunology 41 5-22

Coulam CB and Coulam CH (1992) Update on immunotherapy for recurrent pregnancy loss American Journal of Reproductive Immunology 27 124-127

Fein A, Kostina E, Savion S, Orenstein H, Shepshelovich J, Ornoy A, Torchinsky A and Toder V (2001) Expression of tumor necrosis factor- $\alpha$ in the pregnant uterus of diabetic mice: effect of maternal immunopotentiation American Journal of Reproductive Immunology $\mathbf{4 6}$ 161-168

Fein A, Magid N, Savion S, Orenstein H, Shepshelovich J, Ornoy A, Torchinsky A and Toder V (2002) Diabetes teratogenicity in mice is accompanied with distorted expression of TGF- $\beta 2$ in the uterus Teratogenesis, Carcinogenesis and Mutagenesis 22 59-71

Fisher A, Brandeis R, Chapman S, Pittel Z and Michaelson DM (1998) $M_{1}$ muscarinic agonist treatment reverses cognitive and cholinergic impairments of apolipoprotein E-deficient mice Journal of Neurochemistry 70 1991-1997

Gendron RL, Nestel FP, Lapp WS and Baines MG (1990) Lipopolysaccharideinduced fetal resorption in mice is associated with the intrauterine production of tumour necrosis factor-alpha Journal of Reproduction and Fertility 90 395-403

Godkin JD and Dore JJE (1998) Transforming growth factor $\beta$ and the endometrium Reviews of Reproduction 3 1-6

Gorivodsky M, Zemlyak I, Orenstein H, Savion S, Fein A, Torchinsky A and Toder V (1998) TNF- $\alpha$ messenger RNA and protein expression in the uteroplacental unit of mice with pregnancy loss Journal of Immunology $1604280-4288$

Gorivodsky M, Torchinsky A, Zemliak I, Savion S, Fein A and Toder V (1999) TGF- $\beta 2$ mRNA expression and pregnancy failure in mice American Journal of Reproductive Immunology 42 124-133

Heyborne KD, Witkin SS and McGregor JA (1992) Tumor necrosis factor- $\alpha$ in midtrimester amniotic fluid is associated with impaired intrauterine fetal growth American Journal of Obstetrics and Gynecology 167 920-925
Hunt JS, Atherton RA and Pace JL (1990) Differential responses of rat trophoblast cells and embryonic fibroblast cells to cytokines that regulate proliferation and class I MHC antigen expression Journal of Immunology 145 184-189

Hunt SJ, Chen H and Miller L (1996) Tumor necrosis factors: pivotal components of pregnancy Biology of Reproduction 54 554-562

Ivnitsky I, Torchinsky A, Gorivodsky M et al. (1998) TNF- $\alpha$ expression in embryos exposed to a teratogen American Journal of Reproductive Immunology 40 431-440

Lea RG, Flanders KC, Halkey CB and Clark DA (1992) Release of a transforming growth factor (TGF)- $\beta 2$-related suppressor factor from postimplantation murine decidual tissue can be correlated with the detection of a subpopulation of cells containing RNA for TGF- $\beta 2$ Journal of Immunology 148 778-787

Lea RG, Underwood J, Flanders KC et al. (1995) A subset of patients with recurrent spontaneous abortion is deficient in transforming growth factor $\beta$-2-producing "suppressor cells" in decidua at the placental attachment site American Journal of Reproductive Immunology 34 52-64

Lea RG, Riley SC, Antipatis C, Hannah L, Ashworth CJ, Clark DA and Critchley HOD (1999) Cytokines and the regulation of apoptosis in reproductive tissues: a review American Journal of Reproductive Immunology 42 100-109

Maeda H and Shiraishi A (1996) TGF- $\beta$ contributes to the shift towards Th2 type responses through direct and IL-10-mediated pathways in tumorbearing mice Journal of Immunology 156 73-78

Neta R (1990) Radioprotection and therapy of radiation injury with cytokines Progress in Clinical and Biological Research 352 471-478

Neta R, Douches SD and Oppenheim JJ (1998) Interdependence of the radioactive effects of human recombinant interleukin-1, tumor necrosis factor- $\alpha$, granulocyte-colony stimulating factor and murine recombinant granulocyte-colony stimulating factor Journal of Immunology $\mathbf{1 4 0}$ 108-111

Raghupathy R (1997) Maternal anti-placental cell-mediated reactivity and spontaneous abortions American Journal of Reproductive Immunology 37 478-484

Reznikov LL, Fantuzzi G, Selzman CH, Shames BD, Barton HA, Bell H, McGregor JA and Dinarello CA (1999) Utilization of endoscopic inoculation in a mouse model of intrauterine infection-induced preterm labor: role of interleukin 1 $\beta$ Biology of Reproduction $601231-1238$

Roberts AB, Flanders KC, Kondaiah P et al. (1990) Transforming growth factor $\beta$ : biochemistry and roles in embryogenesis, tissue repair and remodeling and carcinogenesis Recent Progress in Hormone Research 44 157-197

Robertson SA, Seamark RF, Guilbert LG and Wegmann TG (1994) The role of cytokines in gestation Critical Reviews of Immunology 14 239-246

Romero R, Manogue KH, Mitchel MD, Wu KY, Oyarzun E, Hobbins JC and Cerami A (1989) Infection and labor. IV. Cachectin-tumor necrosis factor in the amniotic fluid of women with intraamniotic infection and preterm labor American Journal of Obstetrics and Gynecology 161 336-347

Savion S, Brengauz-Breitmann M, Torchinsky A and Toder V (1999) A possible role for granulocyte macrophage-colony stimulating factor in modulating teratogen-induced effects Teratogenesis, Carcinogenesis and Mutagenesis 19 171-182

Savion S, Lepsky E, Orenstein H, Carp H, Shepshelovich J, Torchinsky A, Fein A and Toder V (2002) Apoptosis in the uterus of mice with pregnancy loss American Journal of Reproductive Immunology 47 1-11

Sokal RR and Rohlf FJ (1995) Multiple comparisons among pairs of means based on unequal sample sizes (unplanned comparisons): the GT2-, T' and Tukey-Kramer methods. In Biometry pp 247-250 Eds RR Sokal and FJ Rohlf. Freeman and Company, New York

Talmadge JE, Tribble $H$, Pennington $R$, Bowersox $O$, Schneider MA Castelli, Black PL and Abe F (1989) Protective, restorative and therapeutic properties of recombinant colony-stimulating factors Blood 73 2093-2103

Tangri S and Raghupathy R (1993) Expression of cytokines in placentas of mice undergoing immunologically mediated spontaneous fetal resorptions Biology of Reproduction 49 850-856 
Tartakovsky B and Ben-Yair E (1991) Cytokines modulate preimplantation development and pregnancy Developmental Biology 146 345-352

Terranova PF, Hunter VJ, Roby KF and Hunt JS (1995) Tumor necrosis factor- $\alpha$ in the female reproductive tract Proceedings of the Society of Experimental Biology and Medicine 209 325-342

Toder V, Strassburger D, Irlin Y, Carp H, Pecht M and Trainin N (1990) Nonspecific immunopotentiators and pregnancy loss: complete Freund adjuvant reverses high fetal resorption rate in $\mathrm{CBA} \times \mathrm{DBA} / 2$ mouse combination American Journal of Reproductive Immunology 24 63-66

Torchinsky A, Fein A and Toder V (1995) Modulation of embryo sensitivity to teratogen by nonspecific intrauterine immunopotentiation Toxicology Methods 5 131-141

Vassali P (1992) The pathophysiology of tumor necrosis factors Annual Review of Immunology 10 411-452

Wegmann TG (1990) The cytokine basis for cross-talk between the maternal immune and reproductive systems Current Opinions in Immunology 2 765-769

Wegmann TG, Athanassakis I, Guilbert IJ, Menu E and Chaouat G (1989) The role of M-CSF and GM-CSF in fostering placental growth, fetal growth and fetal survival Transplantation Proceedings 21 566-568

Wride MA and Semders ED (1995) Potential roles for tumor necrosis factor- $\alpha$ during embryonic development Wilhelm Roux's Archives of Embryology 7 191-201

Received 24 April 2001.

First decision 11 June 2001.

Resubmitted 15 August 2001.

Accepted 15 November 2001. 